\title{
Research on The Application of Multimedia Network Intelligent Classroom in University Classroom
}

\author{
Yi Zhang ${ }^{1, a}$ \\ ${ }^{1}$ Network Information Center, Tonghua Normal University, TongHua, Jilin, China \\ a176325984@qq.com
}

Keywords: Multimedia network intelligent classroom; Modern education; Information transmission

\begin{abstract}
Intelligent multimedia network classroom as a newly emerging teaching mode, has been affirmed by more and more educators. This kind of teaching method has characteristics of fast information transmission, large amount of information and knowledge, teaching diverse, adapt to the traditional education as a new educational mode transformation, effectively improve the traditional education model in the form of a single problem, can effectively improve the students' interest in learning, improve teaching quality, application and advantages of the article on intelligent multimedia network classroom were detailed analysis, fully affirmed the positive role of modern teaching mode.
\end{abstract}

\section{Introduction}

The intelligent multimedia network classroom, can be understood as a diversified, intelligent, a collection of modern computer network technology, multimedia information technology, a new variety of intelligent automatic control technology and other new technology of network technology, not only for a single generation. Writing in traditional education form, but also increased the interaction between students and teachers, the formation of intelligent multimedia network classroom, one can increase the frequency of application of school multimedia equipment and network, saving funds for education, but also can promote the education reform process, help to improve the students' interest in learning. Teachers use intelligent multimedia network classroom is the teacher centered class. In order to change the smart classroom of students as the center. It also makes the classroom knowledge transfer has a new way.

\section{The application mode of the intelligent classroom of multimedia network}

Applied to speech mode. This mode is classroom in advance through the multimedia auxiliary teaching software, the traditional classroom needs the key content of the writing on the blackboard do editing and finishing, broadcast in the classroom using the presentation broadcast function, and the teacher computer display in student machine, use electronic pointer to help students circle the key part, so that the students can be more intuitive understanding of the teaching content, and to don't understand can also repeated viewing. Class time has been fully utilized, the students' learning efficiency thus.

Applied to autonomous learning mode. Teachers can through multi-media equipment, set in advance requires students to think and answer the question, but must be have a certain degree of closure, and let the students using internal LAN connection solves, so to avoid the students because of the network huge attraction and distraction, through the students' self exploration, thinking, will suggests that teachers give their answers, and the multimedia network answer. This study goal, study harder more.

Applied in group solidarity and cooperation. Application between group is refers in the study, the students in a class is divided into different groups to discuss questions, and according to the classroom content set a topic for discussion, students to intelligent multimedia network classroom based, through multimedia network equipment, common discussion and exchange, which makes use of the web application technology, to solve the common problems of teaching. In a simple, friendly, 
healthy page, on the same problem can and put forward the different opinion, everyone can play their intelligence, summed up a solution, so that not only embodies the team cooperation ability, improve the interest in learning.

Applied in class evaluation model. Class evaluation is mainly used in two aspects, of which one is students through multimedia equipment to the classroom learning content questions, intelligent evaluation and scoring multimedia intelligent equipment for students to answer, lets the student understand their master degree, to promote continued learning. On the other hand is by scoring evaluation, performance feedback to the teacher, let the teachers to master the learning situation of students, according to the overall situation of the master course schedule, adjust the teaching rhythm. This is conducive to the interaction between teachers and students and it also is a direct embodiment of the teaching achievement of teachers.

Of course, the application mode of multimedia network classroom intelligent and many, each teacher's usage can also be varied and not the most advanced must be the best, only the most suitable is the best, so in the use of multimedia teaching process, teachers should according to different students set up a multimedia application mode, abilities, improve the practicability of multimedia network intelligent teachers.

\section{Advantages of multimedia network intelligent classroom}

Strong network connection to increase the amount of information, improve the amount of knowledge. Through intelligent multimedia network classroom teaching activities is the biggest difference with the traditional teaching mode is that the knowledge transfer in different ways, intelligent teaching is no longer limited to traditional text and language exchange, more pictures, sound, animation, etc., the classroom can be by the teacher machine, in the network for retrieval of a large number of, and are passed on to every student, so intelligent multimedia network classroom is not only learning in the classroom, is also a library, a language lab, laboratory, both multiple functions in a body, such a strong functional reserve, for students is a kind of influence, the rapid network transmission speed also will promote the improving learning efficiency.

The change of teaching method improves the opportunity of interaction between teachers and students. Traditional classroom questioning is one to one of $\mathrm{Q} \& \mathrm{~A}$, and multimedia network intelligent teachers can improve the single rigid with the software. In the process of teaching teachers can through the host observed every student's learning use, computer operation and master students learning progress, students can also through electronic hand software, at any time to ask questions to the teacher, a to solve a problem, also between students and students, between teachers and students can interact, such exchanges including text, pictures, sound and so on, can effectively improve the traditional model of middle school students and poor situation interaction and improve the quality of learning.

Variety of teaching mode to improve students' subjective initiative. The rich and colorful teaching mode inevitable than traditional forms of writing on the blackboard can attract students attention and improve the students' interest in learning, at the same time, it also changed the tradition of the original with the teacher as the center of the classroom teaching mode, students as the center of the classroom on students in the situation of classroom teaching, students need to master their learning progress, which is helpful for students to improve their subjective initiative, training the ability of autonomous learning.

Strengthen the teaching management process. Intelligent multimedia network classroom is the largest lies in that it can realize the online notification, online monitoring function, teachers can learn at any time for each student to monitor in the process of teaching, teachers can through the machine for every student and control, understand the student's operation, the completion of inspection to strengthen students' learning. The learning process of students management, for students to create a serious, concentrate on learning environment to enable students to concentrate on lectures. In addition, the auxiliary teaching software of modern science can also be analyzed at any time on the learning of students, let the teachers to master the students, get feedback rich information, to help teachers 
according to students the subsequent arrangement of teaching content, to achieve better teaching effect.

Network technology to achieve distance education. Multimedia technology and network technology combined to increase the learning space, enrich the learning content, can realize the effective mode of distance education, students can through the long-distance data transmission, network sharing and teaching resources sharing, by computer or television is like device to achieve distance education learning, accept more knowledge sharing, ultimately achieve cross regional, across time zones, cross national, cross language learning and communication.

Network connectivity to narrow the regional gap. Teaching differences between intelligent multimedia network classroom is a new teaching mode of education and different regions different school teachers and students can learn through a network and communication, so that we can effectively small school, lets the student receive the same level of teaching education, to narrow the gap between students learning, but also can solve the problems of poor teachers in some areas, strengthen the teachers and students learning together.

\section{Conclusion}

The modern society is a rapid development of the information age, digital information era has come before us, the students as the main force of the new era, will become the application technology of the information age. But the traditional education mode must be replaced by the new mode of education reform, education reform and intelligent multimedia network technology is imperative. The classroom has fast transmission of information, information capacity, strong interactivity, diversity of teaching methods and many other features, will help teachers realize the diversity of teaching in the teaching process, interaction and resource sharing. The modern teaching goal should be from the old education into lifelong education, school education for students should be the construction of lifelong, it requires schools to strengthen the teaching of hardware and soft environment, intelligent multimedia network classroom is very well reflected in this day, note Heavy the cultivation of students' ability in many aspects, let memory training transformation for the cultivation of creativity, let the students have stronger practical ability and self-learning ability. Intelligent multimedia network classroom teaching will become the mainstream way of future education and education into the deeper development direction.

\section{References}

[1] Guo J, Zheng J. Research on Application of Multimedia Teaching over Literature Classroom[M]// Advanced Technology in Teaching. Springer Berlin Heidelberg, 2012:465-471.

[2] Liu G H, Meng Q G, Hong-Tao Y U, et al. Research on Status and Countermeasures of Multimedia Classroom Application in Universities of Inner Mongolia[J]. Journal of Inner Mongolia University for Nationalities, 2015, 90:84-94.

[3] Liang B, Xie Y, Huang F, et al. Research on Application of the Internet of Things Technology and Intelligent Multimedia Network Classroom[J]. China Internet, 2013, 12(1):121-132.

[4] Li Q, Wang A, Kai J, et al. Research on Multimedia Intelligence Course and Intelligence Classroom Based on Multiple Intelligence Theory.[C]// International Conference on Intelligent Information Hiding and Multimedia Signal Processing. 2010:398-401.

[5] Lu X. The Application of Multimedia Network Classroom in the Teaching of Computer[J]. Journal of Shanxi Medical University, 2002.

[6] Li Jianqing. Design, construction and management of multimedia classroom[J]. Journal of Huanggang Normal University.2008.3.

[7] Zou Junqiang. The design and construction of multimedia integrated classroom [J]. Journal of University of Electronic Science and Technology of China.2003. 06. 